\title{
Rapid and efficient bioconversion of chicory inulin to fructose by immobilized thermostable inulinase from Aspergillus tubingensis CR16
}

\author{
Sneha Trivedi ${ }^{1}$, Jyoti Divecha ${ }^{2}$, Tapan Shah ${ }^{3}$ and Amita Shah ${ }^{1 *}$
}

\begin{abstract}
Background: Fructose, a monosaccharide, has gained wide applications in food, pharmaceutical and medical industries because of its favourable properties and health benefits. Biocatalytic production of fructose from inulin employing inulinase is the most promising alternative for fructose production. For commercial production, use of immobilized inulinase is advantageous as it offers reutilization of enzyme and increase in stability. In order to meet the demand of concentrated fructose syrup, inulin hydrolysis at high substrate loading is essential.

Results: Inulinase was immobilized on chitosan particles and employed for fructose production by inulin hydrolysis. Fourier transform infrared spectroscopy (FTIR) analysis confirmed linkage of inulinase with chitosan particles. Immobilized biocatalyst displayed significant increase in thermostability at 60 and $65^{\circ} \mathrm{C}$. Statistical model was proposed with an objective of optimizing enzymatic inulin hydrolytic process. At high substrate loading (17.5\% inulin), using $9.9 \mathrm{U} / \mathrm{g}$ immobilized inulinase at $60^{\circ} \mathrm{C}$ in $12 \mathrm{~h}$, maximum sugar yield was $171.1 \pm 0.3 \mathrm{mg} / \mathrm{ml}$ and productivity was $14.25 \mathrm{~g} / \mathrm{l} / \mathrm{h}$. Immobilized enzyme was reused for ten cycles. Raw inulin from chicory and asparagus was extracted and supplied in $17.5 \%$ for enzymatic hydrolysis as a replacement of pure inulin. More than $70 \%$ chicory inulin and $85 \%$ asparagus inulin were hydrolyzed under optimized parameters at $60^{\circ} \mathrm{C}$. Results of high performance liquid chromatography confirmed the release of fructose after inulin hydrolysis.

Conclusions: The present findings prove potentiality of immobilized thermostable inulinase from Aspergillus tubingensis CR16 for efficient production of fructose syrup. Successful immobilization of inulinase on chitosan increased its stability and provided the benefit of enzyme reutilization. Box-Behnken design gave a significant model for inulin hydrolysis. Extraction of raw inulin from chicory and asparagus and their enzymatic hydrolysis using immobilized inulinase suggested that it can be a remarkable cost-effective process for large-scale fructose production.
\end{abstract}

Keywords: Chitosan particles; Inulinase; Immobilization; Thermostable; Inulin hydrolysis; Chicory inulin; Fructose

\section{Background}

From the industrial point of view, fructose is becoming an increasingly important ingredient in food and pharmaceutical products. Fructose is a GRAS sweetener with flavour-enhancing properties. It shows higher solubility and is 1.5 times sweeter than sucrose and thus has preferably replaced sucrose in many foods and beverages [19]. Commercial production of fructose syrup is based on either multienzymatic hydrolysis of starch or less favoured invert sugar production with invertase. Multienzymatic

\footnotetext{
* Correspondence: arshah02@yahoo.com

${ }^{1}$ BRD School of Biosciences, Sardar Patel Maidan, Satellite Campus, Sardar Patel University, P.Box No. 39, Vallabh Vidhyanagar 388120, Gujarat, India Full list of author information is available at the end of the article
}

hydrolysis of starch requires action of three different enzymes with different reaction conditions. Starch is hydrolyzed to dextrins by $\alpha$-amylase, then saccharified to glucose by glucoamylase and finally glucose is isomerised to fructose by glucose isomerase. However, due to the thermodynamical equilibrium, this process yields only $45 \%$ fructose. Another less-favoured approach for obtaining fructose syrup is from the invert syrup obtained from sucrose hydrolysis by the action of invertase. But this process also requires separation of fructose from glucose and thus not preferable at commercial level. Hence, fructose production by inulin hydrolysis is the most advantageous approach as it requires only a single step enzymatic reaction with high fructose yield. Inulin is a well-known 
carbohydrate polymer made up of linear chain of $\beta-2,1$ linked D-fructofuranose molecules which is terminated by a glucose molecule in a sucrose type linkage. Inulin, as a storage polymer, is found in the roots and tubers of many plants of Compositae family, e.g. Jerusalem artichoke, Dahlia, Chicory etc., and because of high content of Dfructose $(>75 \%)$, it is recognized as a raw material for the production of high fructose syrup [30]. In addition to this, inulin has better solubility than starch, in water at higher temperature and forms less viscous solution even at higher concentration [5]. Total or partial hydrolysis of inulin, leading to syrups with high fructose content, can be achieved by the action of inulinases [12]. Inulinases are classified as endoinulinase (2,1- $\beta$-D-fructan fructanohydrolase-EC.3.2.1.7) which act on internal linkages of inulin to release oligosaccharides as end products and exo inulinase ( $\beta$-D-fructan fructanohydrolase-EC.3.2.1.80) which act on terminal molecules to release fructose as an end product. Most of the exoinulinases can hydrolyse sucrose along with inulin. The production of fructose syrup from inulin can be achieved through enzymatic hydrolysis by exoinulinase acting either alone or synergistically with endoinulinase.

Inulin hydrolysis using inulinase proves particularly more effective for industrial purposes if an immobilized form of enzyme is used, as it offers several technological advantages [10]. Chitosan, a partially deacetylated polymer of $\mathrm{N}$-acetyl glucosamine, consists of $\beta(1,4)$-linked $\mathrm{D}$-glucosamine residues and is relatively reactive natural biopolymer. Over the past two decades, various attempts for enzyme immobilization on chitosan particles have been reported. However, preparation processes are found to be tedious and time consuming or contain agents that are harmful to humans, which limit their applications in food and pharmaceutical industries [27]. Thus, there is a need of a simple, yet effective method of immobilization which can be applied for fructose production [18]. In order to meet the demand of concentrated fructose syrup, inulin hydrolysis at high substrate loading is essential. In addition to that, lower complexities as well as concomitant cost reduction are foreseen for the operation of process. This objective can be achieved through the replacement of pure inulin by raw inulin for enzymatic hydrolysis for fructose production. Chicory and asparagus are among the well-known inulin rich crops. In chicory, inulin is stored as a reserve carbohydrate in the fleshy tap root and constitutes about $70-80 \%$ of root dry weight [11]. Asparagus is a perennial herb, which stores up to $15 \%$ inulin in its roots. Raw inulin extraction and hydrolysis from dahlia and asparagus have been studied well, but the reports which describe inulin extraction from chicory and its hydrolysis are very few. In addition to this, studies reported in the literature do not take into account high inulin concentration for inulin hydrolysis which can directly render concentrated fructose syrup.

In the present communication, we report immobilization of indigenously produced inulinase of Aspergillus tubingensis CR16 on chitosan particles and its utilization for the bioconversion of inulin to fructose. Properties of free and immobilized inulinase have been compared. Systematic evaluation of key operational parameters for inulin hydrolysis has been carried out, and an optimized process has been developed using immobilized inulinase. Additionally, raw inulin was extracted from chicory and asparagus and was subjected to enzymatic hydrolysis along with pure chicory inulin. It is worth denoting that we are describing here, inulin bioconversion in a batch reactor, at the highest reported inulin concentration at industrially preferred temperature $\left(60^{\circ} \mathrm{C}\right)$ using immobilized inulinase.

\section{Methods}

\section{Materials}

Inulin (chicory), glutaraldehyde solution and potato dextrose agar (PDA) were from HiMedia, chitosan from shrimp shells (deacetylation $\geq 75 \%$ ) and tripolyphosphate (TPP) were from Aldrich (Sigma). Wheat bran was bought from local vendors of Anand. Corn steep liquor (CSL) was procured from Anil Starch Ltd., Ahmedabad, India. Dry chicory roots were provided by Pioneer Chicory Factory, Anand, India. Asparagus roots were procured from the Directorate of Medicinal Plants and Herbs, Anand. After milling and sieving of dry chicory roots and asparagus roots, the resultant powder was directly used for extraction.

All the other chemicals used were of analytical grade.

\section{Biocatalyst}

Inulinase was produced using wheat bran and corn steep liquor as a substrate under solid state fermentation by $A$. tubingensis CR16 as describe in our earlier work [24]. Crude inulinase was partially purified by ammonium sulphate precipitation (40-80 \%) followed by dialysis against $0.2 \mathrm{M}$ sodium acetate buffer ( $\mathrm{pH}$ 5.0) and was used for immobilization.

\section{Immobilization of inulinase on chitosan particles}

Chitosan particles were synthesized by ionic gelation of chitosan with TPP anions as described by Dounighi et al. [6] with suitable modifications. Size determination and zeta potential of particles were determined by Zetatrac (Microtrac 10.6.1). Surface characteristics of chitosan particles were observed using scanning electron microscopy.

Chitosan support particles were activated with $1.25 \%$ glutaraldehyde solution and immobilization of inulinase was carried out by adding $20 \mathrm{U}$ of inulinase to $100 \mathrm{mg}$ support under mild stirring conditions at $30{ }^{\circ} \mathrm{C}$ for $18 \mathrm{~h}$. Enzyme-loaded chitosan particles were recovered by 
centrifugation at $5000 \mathrm{rpm}$, for $20 \mathrm{~min}$ at $4{ }^{\circ} \mathrm{C}$ and suspended in $0.2 \mathrm{M}$ sodium acetate buffer $\mathrm{pH}$ 5.0. Immobilization yield was calculated as follows:

$$
\text { Immobilization yield }=\left(E_{0}-E_{\mathrm{S}}\right) / E_{0} \times 100
$$

where $E_{0}$ is the free inulinase unit taken for immobilization and $E_{\mathrm{s}}$ is inulinase unit lost in the supernatant.

Activity yield of immobilized inulinase was calculated as

$$
\% \text { Activity yield }=E / E_{\mathrm{I}} \times 100
$$

where $E$ is the inulinase activity obtained using immobilized preparation and $E_{\mathrm{I}}$ is the total inulinase unit immobilized on the support material.

In order to confirm the cross-linking of inulinase on chitosan particles as well as analysing their chemical functionalization, fabricated chitosan particles (with and without inulinase) were subjected to IR analysis using ABB-MB3000 IR analyzer, (ABB India Ltd.)

\section{Inulinase assay}

Inulinase was assayed by measuring the concentration of reducing sugars by 3,5-dinitrosalicylic acid (DNS) [14]. Reaction mixture, consisting of $0.1 \mathrm{ml}$ of appropriately diluted enzyme and $0.9 \mathrm{ml}$ of $1 \%$ inulin in $0.2 \mathrm{M}$ sodium acetate buffer ( $\mathrm{pH} 5$ ), was incubated at $60{ }^{\circ} \mathrm{C}$ for $20 \mathrm{~min}$ and was terminated by further incubation in boiling water bath for $10 \mathrm{~min}$. One unit of inulinase activity was defined as the amount of enzyme necessary to release $1 \mu \mathrm{mol}$ of fructose per minute under the above conditions. Total sugars were analysed as reducing sugars obtained after complete acid hydrolysis of inulin $\left(\mathrm{H}_{2} \mathrm{SO}_{4}, \mathrm{pH} 2.0,100{ }^{\circ} \mathrm{C}, 1 \mathrm{~h}\right)$.

\section{Characterization of immobilized and free inulinase}

Influence of immobilization on physico-chemical properties of inulinase was evaluated. Effect of temperature and $\mathrm{pH}$ on inulinase activity was studied in the range of 50-70 ${ }^{\circ} \mathrm{C}$ and $\mathrm{pH} 3-8$ (0.2 $\mathrm{M}$ citrate buffer for $\mathrm{pH} 3$, $0.2 \mathrm{M}$ sodium acetate buffer for $\mathrm{pH} 4,5$ and $6,0.2 \mathrm{M}$ sodium phosphate buffer for $\mathrm{pH} 7$ and 8), respectively, for free and immobilized inulinase. Temperature stability of immobilized and free inulinase was analysed by incubating enzymes at 60 and $65{ }^{\circ} \mathrm{C}$ for $4 \mathrm{~h}$. Samples were withdrawn at different time intervals and were analysed for residual inulinase activity. Half-life of immobilized and free inulinase was calculated.

\section{Study of enzyme kinetics}

Effect of substrate concentration was evaluated in the range of 0.2 to $2 \%$ inulin concentration at $60{ }^{\circ} \mathrm{C}$. $\mathrm{Km}$ and Vmax for free and immobilized inulinase were determined using Lineweaver-Burk plot.

\section{Optimization of inulin hydrolysis using three factor Box-Behnken design}

Inulin hydrolysis was optimized using response surface methodology with Box-Behnken design (BBD). Three important process parameters, viz. $X_{1}$, enzyme dosage (U/g); $X_{2}$, substrate concentration (inulin \%); and $X_{3}$, time of reaction $(\mathrm{h})$, which play a very crucial role in the inulin hydrolytic process, were selected and considered as independent variables while ln sugar released $(Y)$ was the dependent variable response. Runs were carried out by applying different variables as shown in Table 1. Experimental runs were carried out in duplicates, and temperature $\left(60{ }^{\circ} \mathrm{C}\right)$ and $\mathrm{pH}$ (5.0) were kept constant throughout the experimentation. Each of these independent variables was studied at three different levels as per BBD. A 15 run BBD in original and coded levels $(-1$, 0 and 1), along with experimental and predicted values of sugar released was according to Table 1. Number of experiments $(N)$ required for the development of $\mathrm{BBD}$ was defined as

$$
N=2 k(k-1)+C_{0}
$$

where $k$ is the number of variables and $C_{0}$ was the number of central point [8]. This was used to develop mathematical correlation between the three variables on the release of sugars with a total of 15 runs to fit the polynomial model as per Eq. 1 .

$$
\begin{aligned}
Y=\beta_{0} & +\beta_{1} X_{1}+\beta_{2} X_{2}+\beta_{3} X_{3}+\beta_{11} X_{1}^{2}+\beta_{22} X_{2}^{2} \\
& +\beta_{33} X_{3}^{2}+\beta_{12} X_{1} X_{2}+\beta_{13} X_{1} X_{3}+\beta_{23} X_{2} X_{3}+e
\end{aligned}
$$

Systems were analysed for the release of reducing sugars at specific time interval as planned in BBD. Control reactions were also carried out to discount the presence of sugar out of enzymatic hydrolysis. Statistical analysis was done using software MINITAB 16. Graphs were generated to highlight the roles played by various factors and to emphasize the roles played by physical constraints and biochemical aspects in the final sugar yield released from inulin hydrolysis.

\section{Validation experiment}

Optimized conditions of variables, in the coded form, were decoded as per Eq. 2.

$$
\begin{aligned}
\text { Decoded value of variable }= & (\text { Range of variable } / 2) \text { Coded value } \\
& + \text { Middle value of variable }
\end{aligned}
$$

Runs were carried out under optimized conditions, and reducing sugars were estimated by DNS. The extent of inulin hydrolysis (\%) was calculated as ratio of 
Table 1 BBD design for optimization of inulin hydrolysis as per coded and decoded values of parameters

\begin{tabular}{lccccc}
\hline Run number & Enzyme concentration $(\mathrm{U} / \mathrm{g})$ & Substrate concentration (\%) & Time $(\mathrm{h})$ & $\begin{array}{c}\text { Predicted In sugar } \\
\text { released }(\mu \mathrm{g} / \mathrm{ml})\end{array}$ & $\begin{array}{c}\text { Experimental In sugar } \\
\text { released }(\mu \mathrm{g} / \mathrm{ml})\end{array}$ \\
\hline 1 & $0(5.5)$ & $0(9.25)$ & $0(12)$ & 11.1801 & 11.2912 \\
2 & $-1(1)$ & $0(9.25)$ & $-1(0.5)$ & 8.2346 & 8.6759 \\
3 & $1(10)$ & $0(9.25)$ & $-1(0.5)$ & 9.1342 & 1.2789 \\
4 & $-1(1)$ & $1(17.5)$ & $0(12)$ & 11.2268 & 1.0284 \\
5 & $-1(1)$ & $0(9.25)$ & $1(23.5)$ & 10.4456 & 10.3009 \\
6 & $1(10)$ & $0(9.25)$ & $1(23.5)$ & 11.6786 & 11.2373 \\
7 & $-1(1)$ & $-1(1)$ & $0(12)$ & 6.895 & 6.7968 \\
8 & $1(10)$ & $1(17.5)$ & $0(12)$ & 11.9228 & 12.0209 \\
9 & $0(5.5)$ & $-1(1)$ & $-1(0.5)$ & 5.3199 & 4.9767 \\
10 & $0(5.5)$ & $0(9.25)$ & $0(12)$ & 11.1801 & 10.7729 \\
11 & $0(5.5)$ & $0(9.25)$ & $0(12)$ & 11.1801 & 11.4764 \\
12 & $1(10)$ & $-1(1)$ & $-1(0.5)$ & 8.3317 & 8.8109 \\
13 & $0(5.5)$ & $1(17.5)$ & $1(23.5)$ & 8.2272 & 9.5301 \\
14 & $0(5.5)$ & $-1(1)$ & $1(23.5)$ & 11.659 & 8.4701 \\
15 & $0(5.5)$ & $1(17.5)$ & 12.0021 & \\
\hline
\end{tabular}

reducing sugars released from enzymatic inulin hydrolysis to that from acid hydrolysis multiplied by 100 .

High performance liquid chromatography (HPLC) of inulin hydrolysate was performed against standard glucose, fructose and sucrose solutions using HPLC (Shimadzu, Japan) equipped with Bio-Rad Aminex-87C column with mobile phase $5 \mathrm{mM} \mathrm{H}_{2} \mathrm{SO}_{4}$ and $0.6 \mathrm{ml} / \mathrm{min}$ flow rate at column temperature $65{ }^{\circ} \mathrm{C}$ using RID detector.

\section{Extraction of inulin and raw inulin hydrolysis}

Dried chicory roots and asparagus roots were ground to powdered form. Extraction of inulin from chicory root powder and asparagus root powder was carried out under boiling conditions. Extracts were filtered through muslin cloth. Filtrate was analysed for reducing sugars and total sugars, and inulin content was determined. Raw inulin concentration in both the extracts was adjusted to $17.5 \%$, and hydrolysis was carried out using optimized parameters.

\section{Reusability of immobilized inulinase}

Immobilized inulinase was reused for hydrolysis of $17.5 \%$ inulin using $10 \mathrm{U} / \mathrm{g}$ of enzyme loading for ten successive cycles of $8 \mathrm{~h}$ at $60{ }^{\circ} \mathrm{C}$ and $\mathrm{pH}$ 5.0. Biocatalyst was recovered at $6000 \mathrm{rpm}$, at $4{ }^{\circ} \mathrm{C}$ for $20 \mathrm{~min}$. Hydrolysates were analysed for the amount of reducing sugar released from inulin hydrolysis. The amount of sugar released in the first cycle was considered to be $100 \%$, and the sugar yield of the successive cycles was presented as percentage relative sugar yield.

\section{Results and discussion}

\section{Fabrication of chitosan particles}

Chitosan particles were fabricated by standard ionotropic gelation method using TPP. The size of particles was measured by light scattering analysis. The size of the newly formed chitosan particles was in the range of around 100 to $1000 \mathrm{~nm}$ with an average size of the particles to be $863 \mathrm{~nm}$. It has been reported that chitosan, which is soluble below $\mathrm{pH} 5.5$, can form gels by acting as a polycation, while sodium triphosphate acting as an oppositely charged electrolyte and thereby permitting one to obtain matrices in different shapes and sizes [2]. Zeta potential of the particles was positive $(10.63 \mathrm{mv})$ indicating successful synthesis of chitosan particles. The ionization of basic amino groups $\left(-\mathrm{NH}_{2}\right)$ at acidic $\mathrm{pH}$ leads to the formation of positively charged (protonated) amino $-\mathrm{NH}_{3}^{+}$groups. The positive zeta potential of the fabricated and optimized chitosan particles may be attributed to these ionized and protonated amine groups. The findings of current investigations are in tune with those reported by Wang et al. [27], who confirmed positive value of zeta potential for magnetic chitosan particles $(42.6 \mathrm{mV})$. Topographical characters studied by scanning electron microscopy (Fig. 1) revealed that most of the chitosan particles were nearly spherical while some were irregular in shape.

\section{Immobilization of inulinase}

Immobilization of inulinase was performed on activated chitosan particles. Chitosan particles were activated using $1.25 \%$ glutaraldehyde. Free amino groups present in the chitosan molecule react with free aldehyde group 


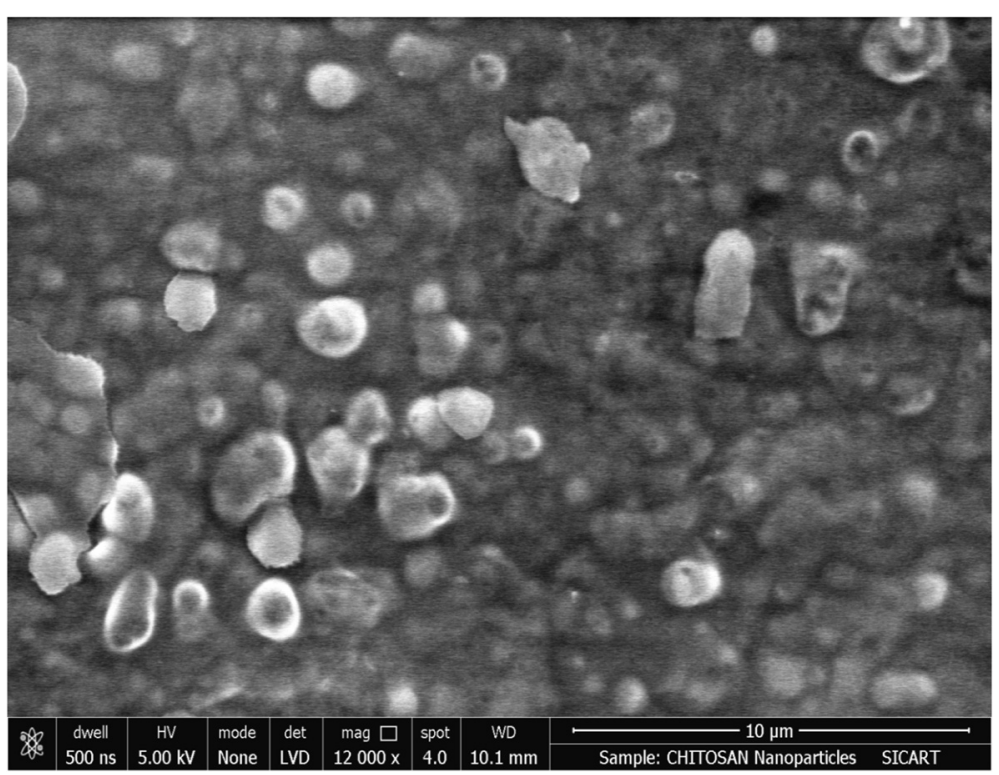

Fig. 1 Scanning electron micrograph of chitosan particles

of glutaraldehyde to form a cross-linked complex. Furthermore, the amino groups present on the enzyme molecule can complex with the free aldehyde groups of glutaraldehyde enabling covalent cross-linking of the enzyme.

Partially purified inulinase (200 U) was added to chitosan particles $(1 \mathrm{~g})$ and was incubated for $18 \mathrm{~h}$. Immobilization yield of $66.4 \pm 0.9 \%$ and activity yield of $36.4 \pm 0.4 \%$ were achieved after $18 \mathrm{~h}$ of incubation. The amount of enzyme units attached per gram of support $(132 \mathrm{U} / \mathrm{g})$ was much higher as compared to other such studies carried out by Gill et al. [9], Ettalibi et al. [1] and Yun et al. [29]. Gill et al. [9] reported immobilization of $30 \mathrm{U} / \mathrm{g}$ of inulinase on chitin with an immobilization yield of $78 \%$ after incubation time of $24 \mathrm{~h}$. Ettalibi et al. [1] have reported inulinase loading of $50 \mathrm{U} / \mathrm{g}$ of porous glass beads as a support and achieved $77 \%$ of immobilization yield after $24 \mathrm{~h}$ of incubation. Similarly, Yun et al. [29] achieved immobilization of $72 \mathrm{U} / \mathrm{g}$ of inulinase on chitosan as a support material, but they were able to immobilize $217 \mathrm{U} / \mathrm{g}$ of inulinase on polystyrene carrier UF93 as a support material.

In the present studies, activity yield was lesser compared to immobilization yield. It is possible that because of immobilization, some active sites may remain unexposed at high enzyme loading. Similar studies have been carried out by Valerio et al. [25], and they have suggested that when higher enzyme concentration is immobilized, the binding sites of the carrier get saturated with enzyme which further leads to diffusion limitation phenomena.

FTIR analysis of inulinase immobilized on chitosan particles Immobilized inulinase was analysed for functionalization by FTIR analysis. IR spectra of the samples were obtained in the range 500 to $4000 \mathrm{~cm}^{-1}$ (Fig. 2a, b). FTIR spectra of glutaraldehyde-activated chitosan particles showed a strong and wide peak in the region of 3000 to $3750 \mathrm{~cm}^{-1}$ attributed to hydrogen-bonded $\mathrm{O}-\mathrm{H}$ stretching vibration (Fig. 2a). IR spectra of immobilized inulinase showed the presence of the peak at $1566 \mathrm{~cm}^{-1}$ which indicated the presence of $\mathrm{N}-\mathrm{H}$ stretching vibrations confirming the cross-linking of glutaraldehyde carboxyl group with the amino groups of the enzyme (Fig. 2b). The presence of another peak at $1412 \mathrm{~cm}^{-1}$ represents $\mathrm{C}-\mathrm{N}$ bond stretching which testifies successful cross-linking between the amino groups of chitosan and the aldehyde group of glutaraldehyde. It has been reported that the aldehyde groups of glutaraldehyde molecules react with the amino groups of chitosan through Schiff base linkage [22]. Other peaks may correspond to the polysaccharide structure of chitosan. Disappearance of certain peaks from activated-chitosan particles (Fig. 2a) and formation of new peaks in the immobilized inulinase spectra (Fig. 2b) confirmed new bond formations and thus cross-linkage between inulinase and activated-chitosan particles.

\section{Effect of temperature on immobilized and free inulinase activity}

Effect of temperature on immobilized inulinase and free inulinase was checked in the range of 50 to $70{ }^{\circ} \mathrm{C}$. The results showed that for immobilized and free inulinase, optimum temperature for enzyme reaction was identical $\left(60{ }^{\circ} \mathrm{C}\right)$ (Fig. 3). It was also evident from the result that in the temperature range examined, relative activity of immobilized inulinase was quite high compared to free 


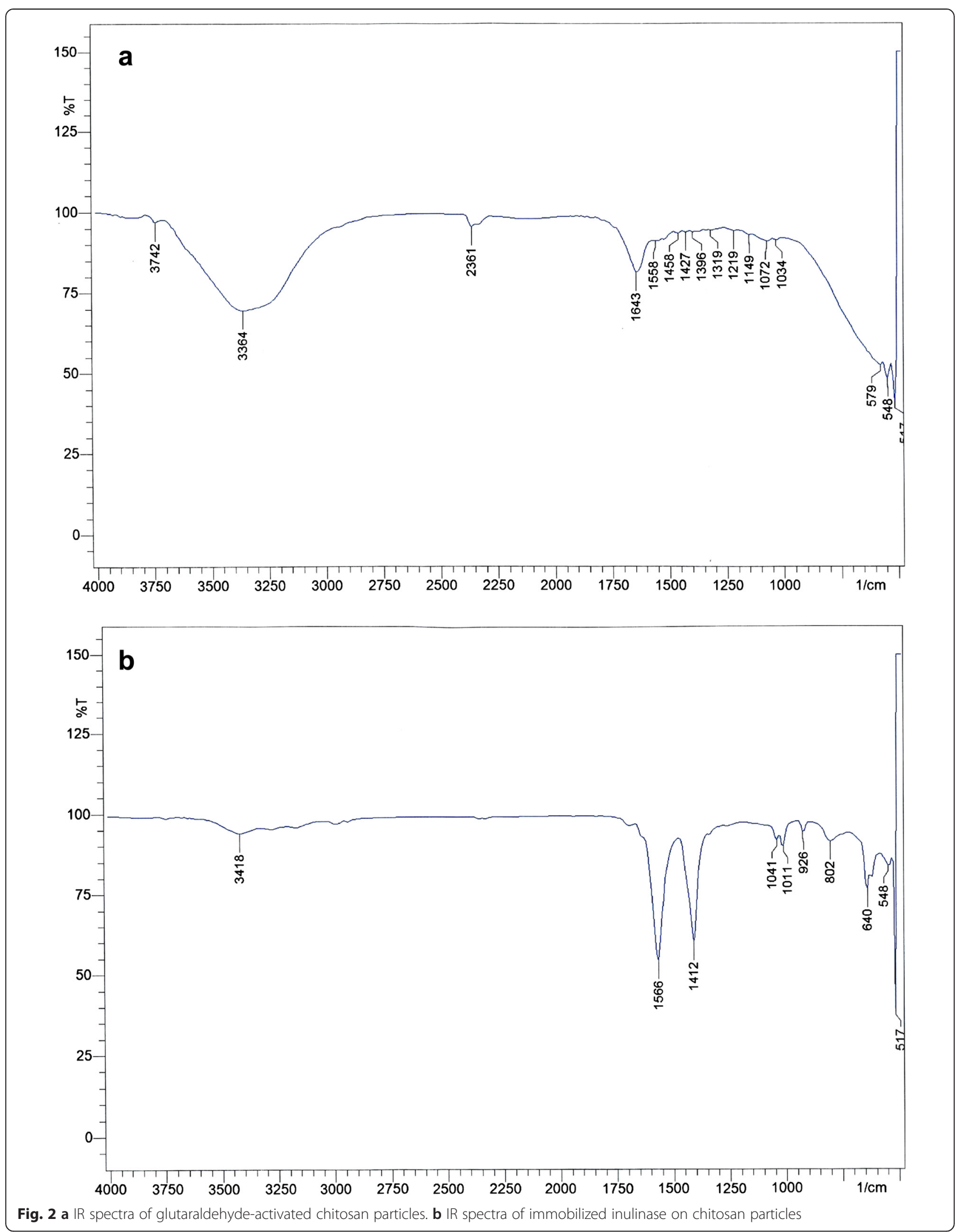




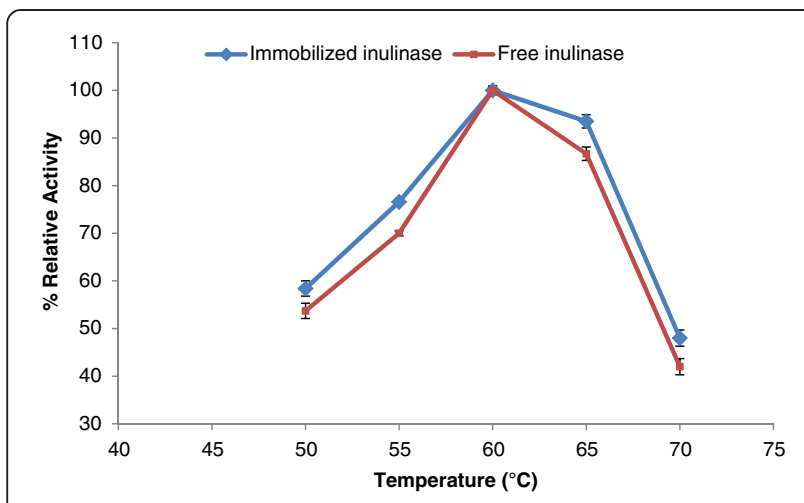

Fig. 3 Effect of temperature on immobilized and free inulinase activity

inulinase which showed that immobilization positively affected the temperature tolerance of inulinase during the reaction. Higher temperature optima for enzyme reaction is critical for industries as it prevents microbial contamination of the final product, lowers viscosity, as well as it allows the use of higher concentrations of inulin due to increased solubility [7]. There are studies performed by Gill et al. [9] and Yun et al. [29] which are in accordance with the present findings. In contrast, there are many reports in the literature indicating shift in optimum temperature of inulinase towards higher or lower values after immobilization $[1,4,18,19]$.

The feasibility of the biotransformation process largely depends on the thermal stability of the biocatalyst, preferably at high temperatures [3]. Although inulinase produced by $A$. tubingensis CR16 was reported to be quite stable at $60{ }^{\circ} \mathrm{C}$ [24], temperature stability studies of immobilized inulinase and its soluble form at two different temperatures, viz. 60 and $65{ }^{\circ} \mathrm{C}$, revealed that immobilization rendered significant enhancement in thermostability of inulinase at both temperatures (Fig. 4). Immobilized inulinase was highly stable at $60{ }^{\circ} \mathrm{C}$ and

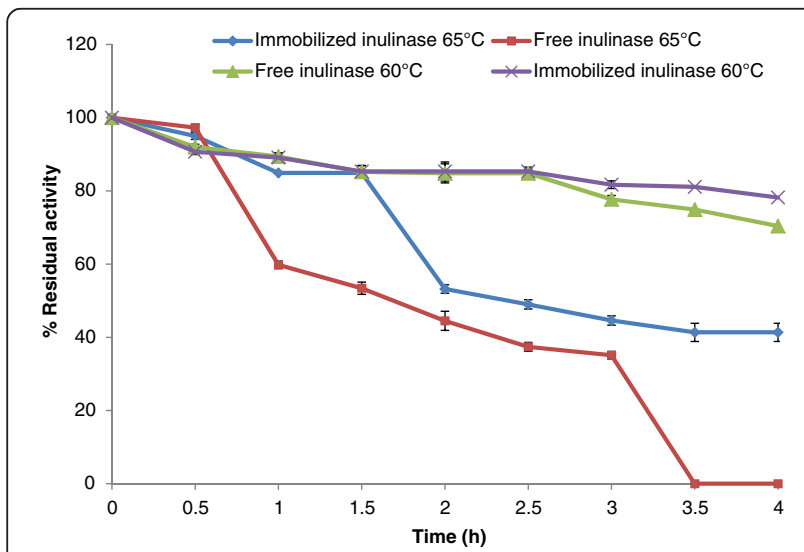

Fig. 4 Thermostability of free and immobilized inulinase at 60 and $65^{\circ} \mathrm{C}$ retained $80 \%$ of its activity after $4 \mathrm{~h}$ whereas free inulinase retained $70 \%$ of its initial activity. At $65{ }^{\circ} \mathrm{C}$, after $4 \mathrm{~h}$ of exposure, when free inulinase was totally inactivated, its immobilized counterpart still retained more than $40 \%$ of its activity. Increase in half-life of inulinase was observed following immobilization which increased to $8.5 \mathrm{~h}$ from $6.6 \mathrm{~h}$ at $60{ }^{\circ} \mathrm{C}$ and $2.7 \mathrm{~h}$ from $1.8 \mathrm{~h}$ at $65^{\circ} \mathrm{C}$, after immobilization. Stability improvement by enzyme immobilization could significantly reduce the operation cost as immobilized enzyme can be reused in more number of batches or for long runs in continuous process at desired temperature in practical applications [27]. It has been well reported that immobilized enzymes are more resistant to high temperatures [29]. Improvement in thermal stability of immobilized inulinase may be due to the covalent cross-linking of enzyme with glutaraldehyde, which protected the conformation of the active site from distortion or damage by heat [17].

\section{Effect of $\mathrm{pH}$ on immobilized and free inulinase activity}

An optimum $\mathrm{pH}$ value depends on the surface charges of an enzyme as well as on the basic character of the support material. Effect of different $\mathrm{pH}$, viz. $\mathrm{pH} 3$ to 8, was checked on immobilized as well as free inulinase activity. Results (Fig. 5) showed that optimum pH (pH 5.0) for inulinase reaction was unaffected by immobilization and remained same for immobilized and free inulinase. It was evident from the $\mathrm{pH}$ profiles of free and immobilized inulinase that immobilization preserved inulinase activity at acidic $\mathrm{pH}$ ( $\mathrm{pH} 3$ and 4) showing higher relative activity compared to free inulinase. Lower $\mathrm{pH}$ optima are advantageous for industrial fructose syrup preparation processes as it lessens the risk of contamination and undesired colour formation. Similar results, to those reported here, were obtained by Gill et al [9]. However, there can also be shift of pH optima after immobilization $[10,16]$.

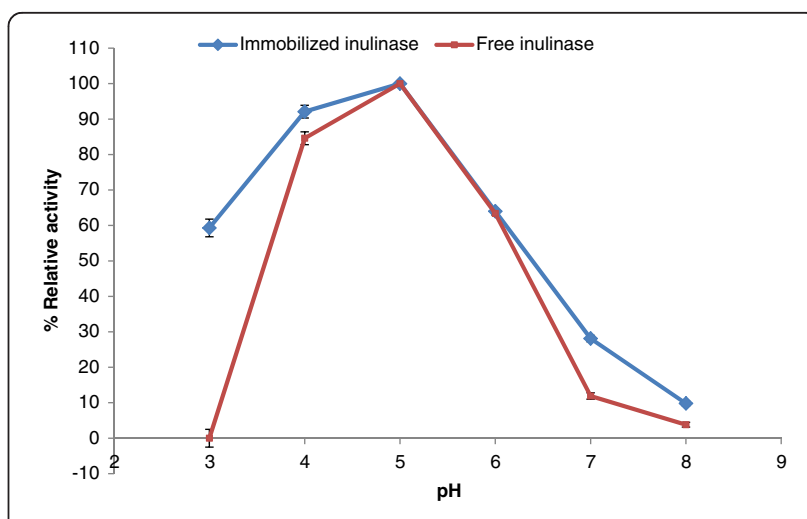

Fig. 5 Effect of pH on the activity of immobilized and free inulinase 
Table 2 Regression coefficients of In sugar released

\begin{tabular}{|c|c|c|c|c|}
\hline Term & Coefficient & Standard error coefficient & $T$ value & $P$ value \\
\hline Constant & 11.1801 & 0.2767 & 40.399 & 0.000 \\
\hline Enzyme concentration (U/g) & 0.5332 & 0.1695 & 3.146 & 0.025 \\
\hline Substrate concentration (\%) & 1.9807 & 0.1695 & 11.688 & 0.000 \\
\hline Time (h) & 1.1889 & 0.1695 & 7.015 & 0.001 \\
\hline Enzyme concentration $(\mathrm{U} / \mathrm{g}) \times$ Enzyme concentration $(\mathrm{U} / \mathrm{g})$ & -0.2335 & 0.2495 & -0.936 & 0.392 \\
\hline Substrate concentration $(\%) \times$ Substrate concentration (\%) & -1.3525 & 0.2495 & -5.422 & 0.003 \\
\hline Time $(h) \times$ Time $(h)$ & -1.0734 & 0.2495 & -4.303 & 0.008 \\
\hline Enzyme concentration $(\mathrm{U} / \mathrm{g}) \times$ Substrate concentration $(\%)$ & -0.1852 & 0.2397 & -0.773 & 0.475 \\
\hline Enzyme concentration $(\mathrm{U} / \mathrm{g}) \times$ Time $(\mathrm{h})$ & 0.0833 & 0.2397 & 0.348 & 0.742 \\
\hline Substrate concentration $(\%) \times$ Time $(h)$ & -0.2648 & 0.2397 & -1.105 & 0.319 \\
\hline
\end{tabular}

\section{Determination of kinetic parameters}

Study of kinetic parameters of free and immobilized inulinase was studied in the range of 0.2 to $2 \%$ inulin. Michaelis-Menten constant calculated for immobilized and free inulinase, from Lineweaver-Burk plot, was 8.3 and $7.4 \mathrm{mg} / \mathrm{ml}$, respectively, showing that immobilization decreased the affinity of inulinase for inulin. This might be because of the change in the charged groups of active sites due to the formation of additional bond between enzymes and support [9]. Vmax for immobilized and free inulinase remained almost unaffected by immobilization (52.6 and $52.0 \mu \mathrm{mol} / \mathrm{ml} / \mathrm{min}$, respectively) revealing that immobilization did not interfere with the reaction velocity.

\section{Optimization of inulin hydrolysis}

Inulinase produced by $A$. tubingensis CR16 was proved to be an exoacting enzyme, which released fructose from inulin [24]. Looking to its catalytic activity, immobilized inulinase was used further for the optimization of process of inulin hydrolysis to get maximum fructose yield. Although many studies on inulin hydrolysis are available in the literature, very few reports describe optimization of inulin hydrolysis using statistical designs $[19,30]$. Hence, statistical approach was applied with an objective of optimizing conditions for maximum fructose production and studying the interactive effects of important parameters simultaneously. Three crucial process parameters, namely inulin concentration (1-17.5\%), enzyme loading (1-10 U/g of substrate) and time of hydrolysis $(0.5-23.5 \mathrm{~h})$ were investigated to get maximum sugar yield. Table 2 indicates the regression coefficients of various combinations. Results were analysed using ANOVA (Table 3), and the second-order regression equation provided the levels of sugar released as the function of inulin concentration, enzyme load and time of hydrolysis. By applying multiple regression analysis on the experimental data, a second-order polynomial equation was obtained in terms of process variables as per Eq. 3 .

$$
\begin{aligned}
Y(\text { ln sugar released })= & 11.1801+0.5332 X_{1} \\
& +1.9807 X_{2}+1.1889 X_{3} \\
& +(-0.2335) X_{1}^{2}+(-1.3525) X_{2}^{2} \\
& +(-1.0734) X_{3}^{2}+(-0.1852) X_{1} X_{2} \\
& +(0.0833) X_{1} X_{3}+(-0.2648) X_{2} X_{3}
\end{aligned}
$$

ANOVA of the second-order regression model demonstrated that the model was highly significant with a $P$ value of 0.001. Lack of fit was insignificant (Table 3). As predicted by the model, all the three parameters were linearly significant along with the inulin concentration and time to be significant at the second order. The pa-

\begin{tabular}{|c|c|c|c|c|c|c|}
\hline Source & $\begin{array}{l}\text { Degree of } \\
\text { freedom }\end{array}$ & Sequential sum of squares & Adjusted sum of squares & Adjusted mean squares & $F$ value & $P$ value \\
\hline Regression & 9 & 55.6704 & 55.6704 & 6.1856 & 26.92 & 0.001 \\
\hline Linear & 3 & 44.9670 & 44.9670 & 14.9890 & 65.24 & 0.000 \\
\hline Square & 3 & 10.2580 & 10.2580 & 3.4193 & 14.88 & 0.006 \\
\hline Interaction & 3 & 0.4455 & 0.4455 & 0.1485 & 0.65 & 0.618 \\
\hline Residual error & 5 & 1.1488 & 1.1488 & 0.2298 & & \\
\hline
\end{tabular}
rameters did not show any interactive effect. However, beyond the middle level, substrate concentration and time tend to show antagonistic effect. The predicted $R^{2}$

Table 3 Analysis of variance for In sugar released 


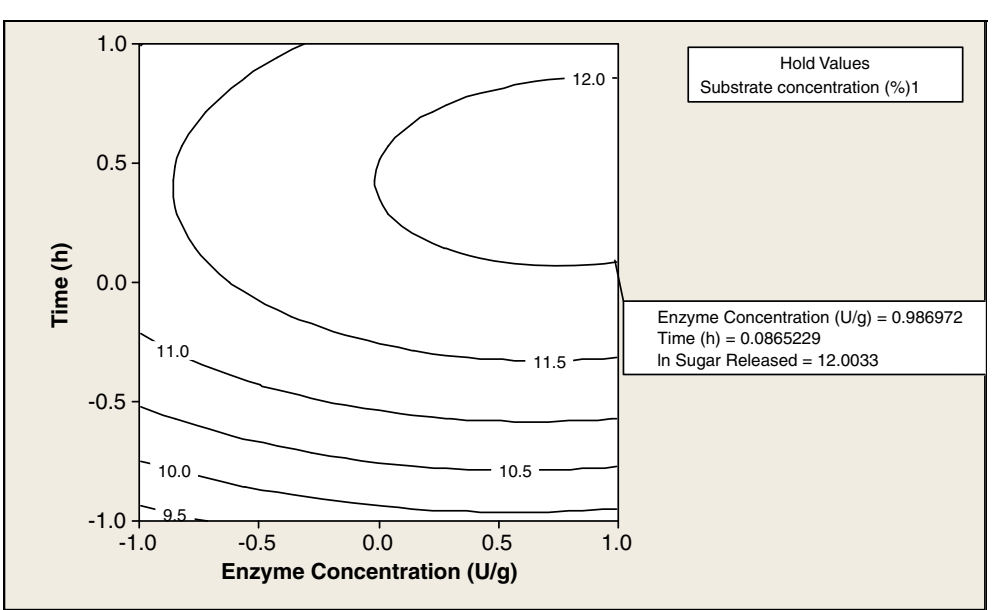

Fig. 6 Contour plot of time versus enzyme concentration

value obtained in this study was quite high at $98 \%$ which was in accordance with the adjusted $R^{2}$ value $(94.3 \%)$ indicating that there was no significant difference between the observed and predicted sugar yield. According to the model, the maximum value of sugar released $(\mathrm{mg} / \mathrm{ml})$ from inulin hydrolysis was predicted to be $\ln 12.00$ which could be obtained using enzyme concentration $0.98(9.9 \mathrm{U} / \mathrm{g})$ with time $0.08(12 \mathrm{~h})$ at the maximum level (1) of substrate concentration (17.5\%) (Fig. 6).

\section{Validation of the experimental model}

In order to determine the accuracy of the model and to validate the model, experiments were repeated in triplicates using the predicted optimized parameters. The yield of reducing sugars was $171.1 \pm 0.3 \mathrm{mg} / \mathrm{ml}$ at $17.5 \%$ inulin using $9.9 \mathrm{U} / \mathrm{g}$ of inulinase after $12 \mathrm{~h}$ reaction time at $60{ }^{\circ} \mathrm{C}$ and was in close accordance with the predicted value (ln 12.00). When compared with the reducing sugars released from the acid hydrolysis of inulin, it was found that more than $95 \%$ of inulin hydrolysis was achieved through enzymatic inulin hydrolysis, using optimized parameters.

In our previous work, inulinase released by $A$. tubingensis CR16 was confirmed to be an exoinulinase [24]. The products of inulin hydrolysis were analysed by HPLC, and it supported our previous result revealing that fructose was the major sugar released from inulin hydrolysis, which was indicated by peak at $11.496 \mathrm{~min}$ of retention time, along with small amount of glucose at peak at $10.319 \mathrm{~min}$ of retention time (Fig. 7). The presence of glucose in inulin hydrolysate was obvious as it is

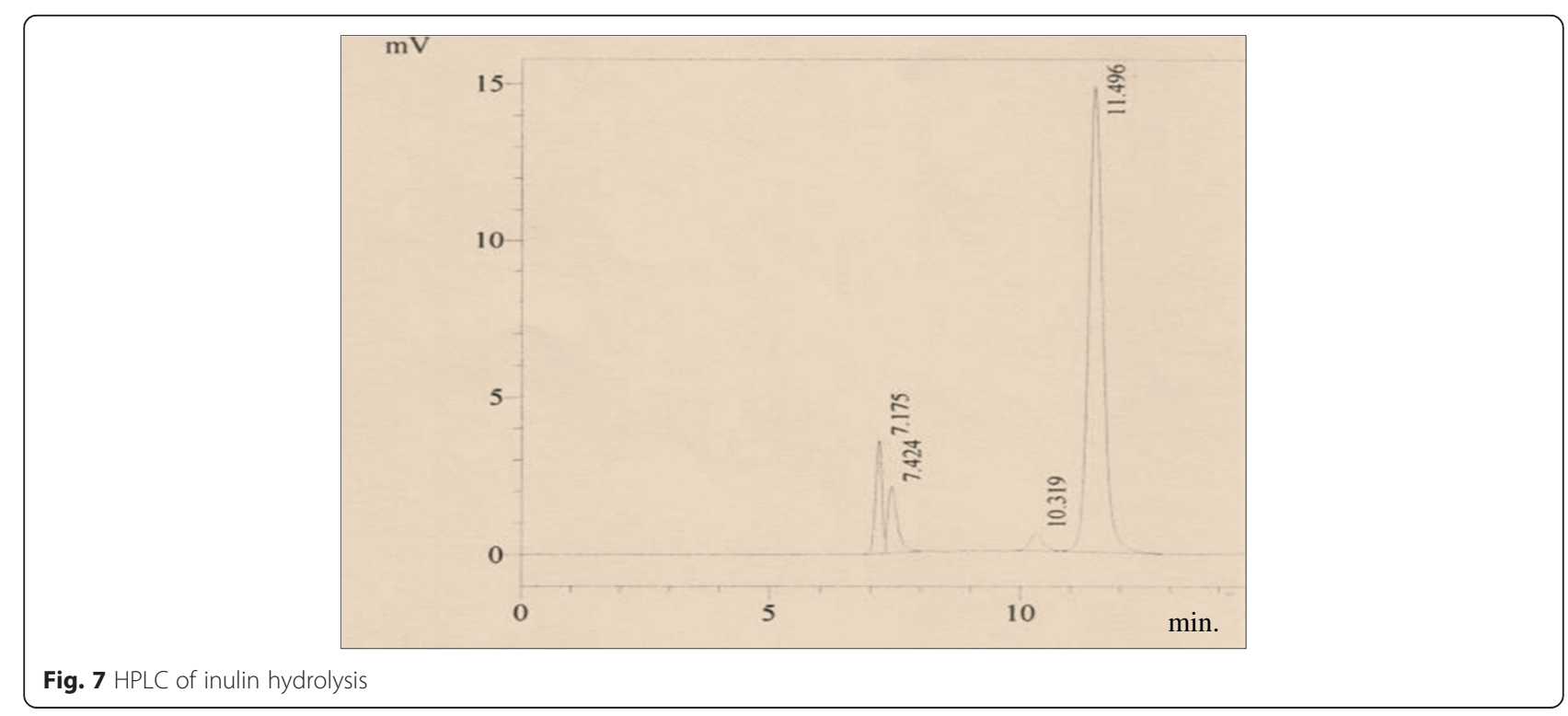




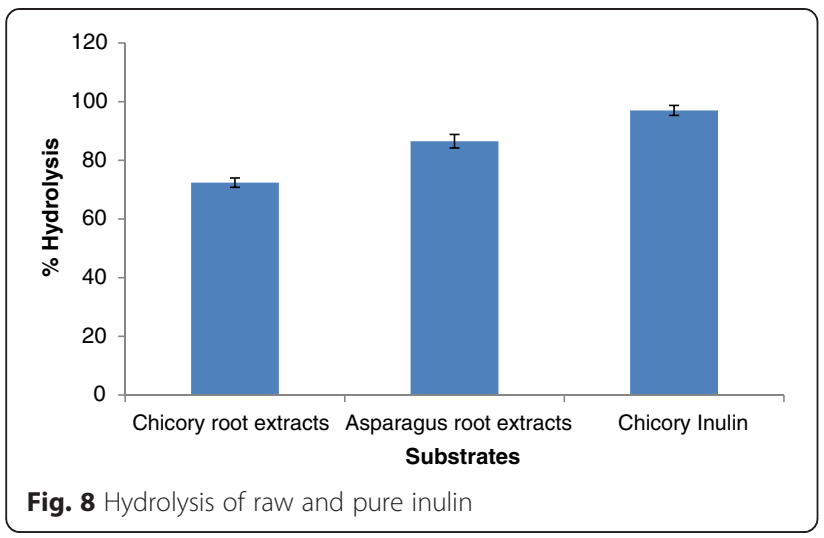

present in inulin as a terminal molecule in a sucrose type linkage.

There are many studies on inulin hydrolysis but to the best of our knowledge, this is the first report of inulin hydrolysis at high substrate concentration with high sugar yield using inulinase immobilized on chitosan particles. The results obtained in the present work were better as compared to the previous reports. Matunda et al. [15] have shown $70.9 \%$ fructose yield by hydrolysis of $15 \%$ inulin using free inulinase from Aspergillus ficuum after $48 \mathrm{~h}$ at $50{ }^{\circ} \mathrm{C}$, while Sirisansaneeyakul et al. [23] reported hydrolysis of $10 \mathrm{~g} / \mathrm{l}$ inulin with fructose yield of $3.7 \%$ after $20 \mathrm{~h}$ at $40{ }^{\circ} \mathrm{C}$ using mixed inulinases from $\mathrm{As}$ pergillus niger and Candida guilliermondii.

\section{Raw inulin extraction and its enzymatic hydrolysis}

Raw inulin sources are abundant in nature and hence can be used as an alternative of pure inulin for the hydrolytic processes. Two of the well-known inulin reservoirs, namely chicory roots and asparagus roots, were processed for inulin extraction. The raw inulin extracted (17.5 \%) was subjected to enzymatic hydrolysis for fructose biosynthesis using immobilized inulinase using

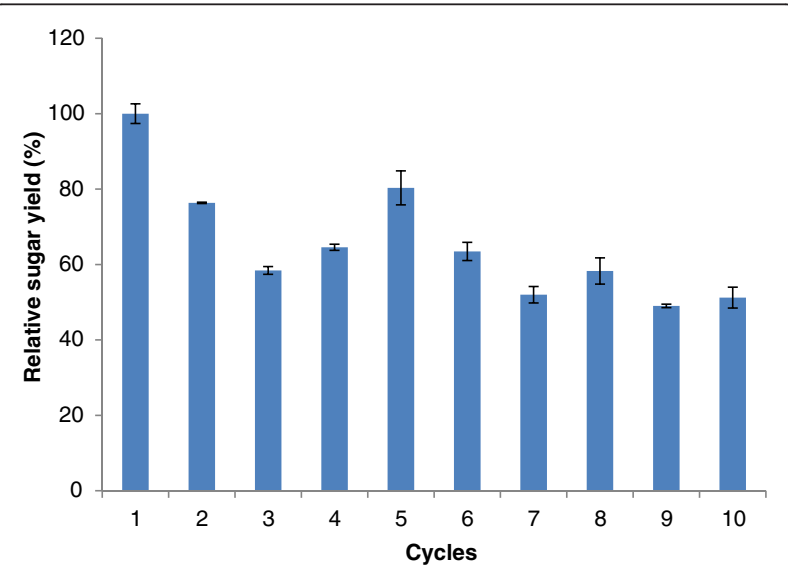

Fig. 9 Reusability of immobilized inulinase for inulin hydrolysis optimized parameters. High yields of reducing sugars were obtained from hydrolysis of both, chicory root extracts as well as asparagus root extracts. More than $70 \%$ hydrolysis of raw chicory inulin and more than $85 \%$ hydrolysis of raw asparagus inulin were achieved in a single catalytic step within $12 \mathrm{~h}$ at $60{ }^{\circ} \mathrm{C}$ (Fig. 8). If the cost of large-scale fructose production is to be foreseen, raw inulin can be a better substitute than pure inulin, which can render the process cost effective. There are reports on raw inulin hydrolysis obtained from Dahlia and asparagus, but only about $5 \%$ inulin concentration has been experimented for hydrolysis which can rather yield less concentrated fructose syrup $[20,21]$. The studies reported here were more promising as it yields fructose syrup from raw inulin in high concentration and at high temperature.

\section{Reusability of immobilized biocatalyst for inulin hydrolysis}

Ease of separation and reusability of enzyme are among the advantages of using an immobilized biocatalyst [19]. In order to minimize the cost of processes, the enzymes are required to be recovered and reused. Thus, reutilization of immobilized inulinase on chitosan particles was evaluated for ten consecutive cycles for the hydrolysis of $17.5 \%$ inulin at $60{ }^{\circ} \mathrm{C}$ for $8 \mathrm{~h}$. In the first cycle, $144.6 \pm 2.5 \mathrm{mg} / \mathrm{ml}$ of reducing sugars was released. However, after the first cycle, there was a marked decrease in the relative sugar yield, but it remained nearly stable in the rest of the sets (Fig. 9). Even after the tenth cycle, about $50 \%$ of sugar yield was obtained as compared to the initial cycle. The enzyme showed increased stability in the presence of its substrate. Significant stability of inulinase for hydrolyzing inulin up to ten cycles at $60{ }^{\circ} \mathrm{C}$ may be attributed to the conformational change or conformational tightening of enzyme in the presence of its substrate $[13,26,28]$. Decrease in the sugar yield after the first cycle could be due to the loss of loosely bound enzyme from its support material. There are very few reports in the literature regarding reusability of immobilized inulinase in batch reactor. Rocha et al. [19] has reported reusability of Amberlite immobilized inulinase for seven cycles for the hydrolysis of $0.5 \%$ inulin.

\section{Conclusions}

The present study describes the successful application of immobilized inulinase from $A$. tubingensis CR16 for the production of fructose syrup by inulin hydrolysis. Inulinase was immobilized on chitosan particles with $66.4 \pm$ $0.9 \%$ immobilization yield and $36.4 \pm 0.4 \%$ activity yield. Immobilization increased thermal stability of inulinase. Statistical optimization of inulin hydrolysis depicted the parameters which could give the maximum possible fructose yield. Also, it is worth mentioning that even at 
very high inulin concentration (17.5\%) more than $95 \%$ inulin hydrolysis was achieved from pure inulin. Along with that, high concentration of raw inulin from chicory roots and asparagus roots were hydrolysed at $60{ }^{\circ} \mathrm{C}$ after $12 \mathrm{~h}$ in a single step. Immobilized inulinase was found to be reusable for ten cycles. Thus, the above findings prove the potential of immobilized inulinase for inulin hydrolysis for large-scale fructose production at industrial level.

\section{Competing interests}

The authors declare that they have no competing interests.

\section{Author's contributions}

ST designed and performed the experiments along with the data analysis and organized the manuscript draft. JD designed and analysed statistical optimization data for hydrolysis. TS made conceptual contributions regarding the synthesis of chitosan particles and immobilization of enzyme. AS supervised the complete study along with experimentation, interpretation and manuscript drafting. All the authors read and approved the final manuscript.

\section{Acknowledgements}

ST acknowledges the staff of Shree P.M.Patel College of Paramedical Science and Technology for their kind cooperation.

\section{Author details}

'BRD School of Biosciences, Sardar Patel Maidan, Satellite Campus, Sardar Patel University, P.Box No. 39, Vallabh Vidhyanagar 388120, Gujarat, India. ${ }^{2}$ Department of Statistics, Sardar Patel University, Vallabh Vidhyanagar 388120Gujarat, India. ${ }^{3}$ Centre for Nanoscience and Engineering, IISC, Bengaluru, Karnataka, India.

Received: 1 April 2015 Accepted: 29 June 2015

Published online: 15 July 2015

\section{References}

1. And EM, Baratti JC (2001) Sucrose hydrolysis by thermostable immobilized inulinases from Aspergillus ficuum. Enzyme Microb Technol 28:596-601

2. Carrara CR, Rubiolo AC (1994) Immobilization of $\beta$-galactosidase on chitosan. Biotechnol Prog 10:220-224

3. Catana R, Eloy M, Rocha JR, Ferreira BS, Cabral JMS, Fernandes P (2007) Stability evaluation of an immobilized enzyme system for inulin hydrolysis. Food Chem 101:260-266

4. Catana R, Ferreira BS, Cabral JMS, Fernandes P (2005) Immobilization of inulinase for sucrose hydrolysis. Food Chem 91:517-520

5. Chi ZM, Zhang T, Cao TS, Liu XY, Cui W, Zhao CH (2011) Biotechnological potential of inulin for bioprocesses. Bioresour Technol 102:4295-4303

6. Dounighi MN, Eskandar R, Avadi MR, Zolfagharian H, Sadeghi A, Rezayat M (2012) Preparation and in vitro characterization of chitosan nanoparticles containing Mesobuthus eupeus scorpion venom as an antigen delivery system. J Venomous Anim Toxins including Tropical Dis 18(1):44-52

7. Fawzi EM (2011) Comparative study of two purified inulinases from thermophile Thielavia terrestris NRRL 8126 and mesophile Aspergillus foetidus NRRL 337 grown on Chicorium intybus L. Braz J Microbiol 42:633-649

8. Ferreira SLC, Bruns RE, Ferreira HS, Matos GD et al (2007) Box-Behnken design: an alternative for the optimization of analytical methods. Anal Chemi Acta 597:179-186

9. Gill PK, Manha RK, Singh P (2006) Hydrolysis of inulin by immobilized thermostable extracellular exoinulinase from Aspergillus fumigatus. J Food Eng 76:369-375

10. Gomez L, Ramirez HL, Villalonga ML, Hernandez J, Villalonga R (2006) Immobilization of chitosan — modified invertase on alginate coated chitin support via polyelectrolyte complex formation. Enzyme Microb Technol 38:22-27

11. Gupta AK, Kaur N, Kaur N (2003) Preparation of inulin from chicory roots. J Sci Ind Res 62:916-920

12. Kochhar A, Gupta AK, And KN (1999) Purification and immobilisation of inulinase from Aspergillus candidus for producing fructose. J Sci Food Agric 79:549-554
13. Lejeune A, Vanhove M, Brasseur JL, Pain RH, Frere JM, Matagne A (2001) Quantitative analysis of the stabilization of substrate of $S$. aureus PC1 B-lactamase. Chem Biol 8:831-842

14. Miller GL (1939) Use of dinitrisalicylic acid reagent for determination of reducing sugar. Anal Chem 31:426-428

15. Mutanda T, Wilhelmi B, Whiteley CG (2009) Controlled production of fructose by an exoinulinase from Aspergillus ficuum. Appl Biochem Biotechnol 159:65-77

16. Naby MA, Sherif AA, Tanash AB, Mankariosh AT (1999) Immobilization of Aspergillus oryzae tannase and properties of the immobilized enzyme. J Appl Microbiol 87:108-114

17. Nguyen QD, Rezessy-Szabo JM, Czukor B, And HA (2011) Continuous production of oligofructose syrup from Jerusalem artichoke juice by immobilized endo-inulinase. Process Biochem 46:298-303

18. Paula FC, Cazetta ML, Monti R, Contiero J (2008) Sucrose hydrolysis by gelatine-immobilized inulinase from Kluyveromyces marxianus var. Bulgaricus. Food Chem 111:691-695

19. Rocha JR, Catana R, Ferreira BS, Cabral JMS, Fernanades P (2006) Design and characterisation of an enzyme system for inulin hydrolysis. Food Chem 95:77-82

20. Singh RS, Dhaliwal R, Puri M (2007) Production of high fructose syrup from asparagus inulin using immobilized exoinulinase from Kluyveromyces marxianus YS-1. J Ind Microbiol Biotechnol 34:649-655

21. Singh RS, Dhaliwal R, Puri M (2008) Development of a stable continuous flow immobilized enzyme reactor for the hydrolysis of inulin. J Ind Microbiol Biotechnol 35:777-782

22. Singh AN, Singh S, And SN, Dubey VK (2011) Gluteraldehyde-activated chitosan matrix for immobilization of a novel cysteine protease, procerain B. J Agric Food Chem 59:6256-6262

23. Sirisansaneeyakul S, Worawuthiyanan N, Vanichsriratana W, Srinophakun P, Chisti Y (2007) Production of fructose from inulin using mixed inulinases from Aspergillus niger and Candida guilliermondii. World J Microbiol Biotechnol 23:543-552

24. Trivedi S, Divecha J, Shah A (2012) Optimization of inulinase production by a newly isolated Aspergillus tubingensis CR16 using low cost substrates. Carbohydrates Polymers 90:483-490

25. Valerio SG, Alves JS, Klein MP, Rodrigues RC, Hertz PF (2013) High operational stability of invertase from Saccharomyces cerevisiae immobilized on chitosan nanoparticles. Carbohydr Polym 92:462-468

26. Varga A, Flachner B, Graczer E, Szaboles O, Szilagyi AN, Vas M (2005) Correlation between conformational stability of the ternary enzyme-substrate complex and domain closure of 3-phosphoglycerate kinase. FEBS J 272(8):1867-1885

27. Wang J, Zhao G, Li Y, Liu X, Hou P (2013) Reversible immobilization of glucoamylase onto magnetic chitosan nanocarriers. Appl Microbiol Biotechnol 97:681-692

28. Warmerdam A, Boom RM, Janssen AEM (2013) $\beta$-galactosidase stability at high substrate concentrations. Springer plus 2:402

29. Yun JW, Park JP, Song CH, Lee CY, Kim JH, Song SK (2000) Continuous production of inulooligosaccharides from chicory juice by immobilized endoinulinase. Bioprocess Eng 22:189-194

30. Zhengyu J, Jing W, Bo J, Xueming X (2004) Production of inulooligosaccharides by endoinulinase from Aspergillus ficuum. Food Res Int 38:301-308

\section{Submit your manuscript to a SpringerOpen ${ }^{\circ}$ journal and benefit from:}

- Convenient online submission

- Rigorous peer review

- Immediate publication on acceptance

- Open access: articles freely available online

- High visibility within the field

- Retaining the copyright to your article

Submit your next manuscript at $\boldsymbol{\wedge}$ springeropen.com 